\title{
Pengembangan Situs Sistem Pendaftaran Online Peserta Ujian Mandiri Universitas Negeri Jakarta
}

\author{
Akbar Kusuma Negara, Widodo, M. Ficky Duskarnaen ${ }^{2}$ \\ 1,2,3 Pendidikan Teknik Informatika dan Komputer Fakultas Teknik \\ Universitas Negeri Jakarta \\ akbarkusumanegaralth@gmail.com,widodo@unj.ac.id, duskarnaen@unj.ac.id
}

\begin{abstract}
ABSTRAK
Banyaknya pendaftar ujian mandiri Universitas Negeri Jakarta menjadi sebuah landasan untuk membuat sebuah sistem pendaftaran online yang dapat melayani calon peserta dari seluruh kota di Indonesia dengan mudah. Pengembangan sistem pendaftaran online ujian mandiri Universitas Negeri Jakarta selalu dilakukan setiap tahun untuk meningkatkan pelayanan dan memperbaiki kesalahan teknis pada sistem yang ada sebelumnya. Tujuan penelitian ini adalah untuk mengembangkan sebuah situs pendaftaran online Peserta Ujian Mandiri Universitas Negeri Jakarta yang sistematis dan user-friendly. Penelitian dilakukan di Pusat Teknologi Informasi dan Komunikasi Universitas Negeri Jakarta (PUSTIKOM UNJ) dari bulan Februari 2015 hingga Juni 2015. Metode penelitian yang digunakan adalah Research and Development, dan metode pengembangan perangkat lunak yang digunakan adalah metode Spiral. Berdasarkan hasil uji coba Black-Box, situs pendaftaran online ini telah terbukti berfungsi sesuai dengan yang diharapkan.
\end{abstract}

Kata kunci: Situs pendaftaran online, Metode Spiral, Black-Box testing.

\section{PENDAHULUAN}

Berdasarkan pasal 5 Peraturan Menteri Riset, Teknologi, Dan Pendidikan Tinggi Republik Indonesia Nomor 2 Tahun 2015, menyebutkan bahwa jumlah alokasi daya tampung mahasiswa baru program sarjana pada perguruan tinggi negeri, yaitu paling sedikit 50\% (lima puluh persen) pada setiap program studi yang diterima melalui SNMPTN; paling sedikit 30\% (tiga puluh persen) pada setiap program studi yang diterima melalui SBMPTN; dan paling banyak $20 \%$ (dua puluh persen) pada setiap program studi yang diterima melalui penerimaan mahasiswa baru secara mandiri yang dilaksanakan oleh masing-masing perguruan tinggi negeri. ${ }^{[1]}$ Untuk memenuhi kuota 20\% yang diberikan secara mandiri, maka Universitas Negeri Jakarta mengadakan sistem ujian mandiri yang lebih dikenal dengan Penerimaan Mahasiswa Baru Universitas Negeri Jakarta (PENMABA UNJ), PENMABA UNJ merupakan salah satu jalur penerimaan mahasiswa yang dilaksanakan secara mandiri oleh UNJ.

Setiap tahunnya, UNJ menarik banyak perhatian dan minat seluruh peserta di seluruh Indonesia hingga mencapai belasan ribu untuk merebutkan program studiprogram studi yang ada di UNJ. Untuk mempermudah peminat tersebut melakukan pendaftraran ujian, maka dibuatlah situs sistem pendaftaran online peserta ujian mandiri. Akan tetapi dalam penerapan sistem pendaftaran secara online, ternyata masih terdapat masalah seperti misalnya terjadi kasus dimana pendaftar mengisikan 
data diri tetapi tidak melanjutkan hingga proses pembayaran. Dengan ini maka pendaftar dinyatakan batal mendaftar, akan tetapi data yang sudah diinput pendaftar tersebut sudah tersimpan dalam database server dan tentunya menambah beban server saat proses loading data. Selain itu, terjadi juga asinkronisasi antara database server UNJ dengan database host to host, kasus dimana tagihan pembayaran tercatat dalam database server tetapi tidak tercatat dalam database host to host.

Mengingat jumlah pendaftar yang mencapai belasan ribu dan masalah yang pernah terjadi, maka perlu dianalisis dan dicari solusi paling efektif untuk meminimalkan kesalahan teknis. Diperlukan pengembangan untuk perancangan dan analisis yang matang baik dari segi fungsional maupun non-fungsional sangat dibutuhkan agar terciptanya sistem pendaftaran online PENMABA UNJ yang efektif dan efisien hingga akhirnya dapat dimanfaatkan oleh pihak UNJ.

\section{PENGERTIAN SISTEM}

Sistem adalah suatu kesatuan yang terdiri dari komponen atau elemen yang dihubungkan bersama untuk memudahkan aliran informasi, materi, atau energi untuk mencapai suatu tujuan. ${ }^{[1]}$ Sedangkan menurut Burch dan Strater ${ }^{[2]}$, kata 'sistem' berasal dari bahasa Yunani, yaitu systema yang berarti kesatuan, yakni keseluruhan bagian-bagian yang mempunyai hubungan satu dengan yang lainnya. "Suatu sistem dapat dirumuskan sebagai setiap kumpulan bagian - bagian atau subsistem-subsistem yang disatukan, yang dirancang untuk mencapai suatu tujuan".

Karakteristik sistem yang dapat membedakan suatu sistem dengan yang lain adalah sebagai berikut: ${ }^{[3]}$

1. Batasan

Merupakan gambaran dari suatu elemen mana yang termasuk didalam sistem dan mana yang diluar sistem.

2. Lingkungan
Segala sesuatu diluar sistem yang menyediakan asumsi, kendala dan input terhadap sistem.

3. Masukan

Sumber daya dari lingkungan yang dikonsumsi dan dimanipulasi oleh suatu sistem.

4. Keluaran

Sumber daya atau produk yang disediakan untuk lingkungan sistem oleh kegiatan dalam suatu sistem.

5. Komponen

Kegiatan-kegiatan dalam suatu sistem yang mentransformasikan input menjadi bentuk setengah jadi.

6. Penghubung

Tempat dimana komponen dan lingkungannya saling bertemu kemudian berinteraksi.

7. Penyimpanan

Area yang dikuasai dan digunakan untuk penyimpanan sementara dan tetap dari informasi, bahan baku dan sebagainya.

Dari pengertian diatas dapat dipahami bahwa sistem adalah sekumpulan dari beberapa komponen terorganisir guna mengolah dan mentransformasikan data untuk mencapai tujuan tertentu.

\subsection{Sistem Online}

Website atau situs merupakan kumpulan beberapa halaman pribadi, organisasi, atau perusahaan yang menampilkan dan memuat informasi dalam web server (suatu unit komputer yang berfungsi untuk menyimpan informasi dan mengelola jaringan komputer). ${ }^{[4]}$ Informasiinformasi dalam website biasanya dapat dilihat secara online.

Situs pendaftaran ujian mandiri Universitas Negeri Jakarta, menampilkan informasi - informasi yang berkenaan dengan tata cara pendaftaran ujian hingga sampai pelaksanaan ujian. Akan tetapi tujuan utama situs ini adalah, memudahkan peserta dari berbagai kota di seluruh Indonesia untuk mendaftarkan diri mengikuti ujian secara online. Sistem pendaftaran ujian mandiri ini akan mengumpulkan, mengolah dan 
mentransformasikan data pendaftar melalui media website.

Online merupakan suatu kegiatan yang dilakukan pada sebuah perangkat yang terkoneksi dengan jaringan internet ${ }^{[5]}$. Di era yang sudah tanggap dengan teknologi, sudah bukan merupakan suatu ketidakmungkinan bagi seseorang untuk melakukan aktivitas secara online. Menghemat tenaga, waktu, dan uang, tentunya hal ini memberikan kemudahan bagi pihak penyelenggara dan pendaftar ujian mandiri untuk saling bertukar informasi dengan cara yang lebih efektif.

Dengan menggabungkan pengertian sistem dan pengertian online yang telah dijelaskan sebelumnya, maka dapat ditarik pengertian bahwa sistem online adalah suatu rangkaian kegiatan yang saling berkaitan, bertransformasi guna menghasilkan tujuan tertentu yang dilakukan menggunakan perangkat yang terhubung koneksi internet.

\subsection{Konsep Pengembangan Sistem}

Dalam proses pengembangan sistem, dibutuhkan metode-metode tertentu untuk menjadi panduan dalam mengembangkan sistem. Metode pengembangan sistem sendiri menurut Satzinger, Jackson dan Burd $^{[6]}$ adalah acuan yang dapat diikuti untuk menyelesaikan setiap aktivitas dalam pengembangan sistem, termasuk models, tools, dan teknik-teknik tertentu. Model dalam definisi ini adalah perumpamaan dari aspek penting dalam dunia nyata, sedangkan tools berupa software pendukung yang membantu dalam pembuatan model atau komponen lain yang dibutuhkan dalam pengembangan sistem.

Metode penelitian yang digunakan dalam penelitian ini adalah Metode Research and Development $(R \& D)$. Metode penelitian $R \& D$ adalah metode penelitian yang digunakan untuk menghasilkan produk tertentu, dan menguji keefektifan produk tersebut. Produk tersebut tidak selalu berbentuk benda atau perangkat keras (hardware), seperti buku, alat tulis, dan alat pembelajaran lainnya, dapat pula dalam bentuk perangkat lunak (software). ${ }^{[5]}$

\subsection{Ujian Mandiri UNJ}

Ujian mandiri merupakan ujian yang persyaratan maupun mekanisme pelaksaaannya diserahkan sepenuhnya kepada perguruan tinggi masing - masing. Seperti telah diketahui, bidang ilmu dalam jalur ujian mandiri ada dua, yaitu Ilmu Pengetahuan Alam (IPA) dan Ilmu Pengetahuan Sosial (IPS). Para calon mahasiswa dapat memilih satu sampai tiga jurusan atau program studi dari kelompok bidang ilmu tersebut.

Ujian Mandiri Masuk Universitas Negeri Jakarta lebih dikenal dengan Penerimaan Mahasiswa Baru UNJ (PENMABA UNJ). PENMABA UNJ merupakan salah satu jalur penerimaan mahasiswa yang dilaksanakan secara mandiri oleh UNJ. PENMABA UNJ pertama kali dilaksanakan tahun 2009. Pelaksanaan PENMABA UNJ menggunakan sistem ujian tertulis yang memperhatikan potensi akademik yang sesuai dengan program studi yang dipilih oleh calon mahasiswa. Prinsip utama PENMABA UNJ adalah adil dan tidak diskriminatif dengan tidak membedakan jenis kelamin, agama, suku, ras, kedudukan sosial, serta tingkat kemampuan ekonomi calon mahasiswa. Peserta PENMABA UNJ dapat berasal dari lulusan SLTA (berijazah SLTA/yang sederajat) untuk memasuki program D-III dan S1, maupun lulusan DI/D-II/D-III dari perguruan tinggi negeri/terakreditasi untuk memasuki program S1 (alih program). Alih program dapat juga diperuntukkan bagi peminat yang akan mengambil S1 kedua. Di samping itu, penerimaan mahasiswa baru dapat melalui program kerjasama dengan instansi pemerintah maupun non pemerintah melalui persetujuan yang disahkan oleh Rektor. ${ }^{[7]}$

PENMABA UNJ menawarkan 67 program studi kepada calon mahasiswa. Oleh sebab itu, untuk memperbesar peluang diterimanya calon mahasiswa maka pada PENMABA UNJ, para calon mahasiswa dapat memilih satu sampai tiga program studi di UNJ. Terdapat tiga kategori ujian 
dalam pelaksanaan PENMABA UNJ, yaitu kategori IPA, kategori IPS, dan kategori IPC. Peserta ujian dinyatakan melaksanakan ujian kategori IPA saat memilih satu sampai dua program studi yang terdapat dalam kelompok program studi IPA, dinyatakan melaksanakan ujian kategori IPS saat memilih satu sampai dua program studi yang terdapat dalam kelompok program studi IPS, dan dinyatakan melaksanakan ujian kategori IPC saat memilih tiga program studi dengan pilihan minimal satu program studi yang terdapat di kelompok program studi IPA dan dua program studi IPS atau sebaliknya.

\subsection{Batasan Pengembangan Sistem}

Alur sistem ini dirancang mengikuti mekanisme pembayaran yang telah disepakati pihak penyelenggara dengan bank. Pada pendaftaran tahun ini, pembayaran hanya dilakukan satu kali setelah calon peserta mencetak slip tagihan dengan nominal yang tertera pada slip tagihan. Adapun banyaknya jumlah pendaftar tidak dibatasi yang berarti penyelenggara tidak perlu melakukan pembelian voucher dari bank.

\section{METODE PENGEMBANGAN PERANGKAT LUNAK SPIRAL}

Dalam mengembangkan penelitian ini, metode pengembangan perangkat lunak yang digunakan adalah Metode Spiral. Metode Spiral adalah model proses pengembangan perangkat lunak evolusioner yang menggabungkan pendekatan prototyping yang sifatnya iteratif dengan aspek-aspek sistematis dan terkendali seperti yang dijumpai pada metode waterfall. $^{[8]}$ Penggunaan metode Spiral dalam penelitian ini terdiri dari 4 aktivitas, yaitu:

1. Perencanaan (Planning), penentuan tujuan, alternatif dan batasan.

2. Analisis resiko (Risk Analysis), analisis alternatif dan identifikasi/pemecahan resiko.

3. Rekayasa Sistem (Engineering), pengembangan level berikutnya dari produk.
4. Evaluasi Pemakai (Customer Evaluation) penilaian terhadap hasil rekayasa.

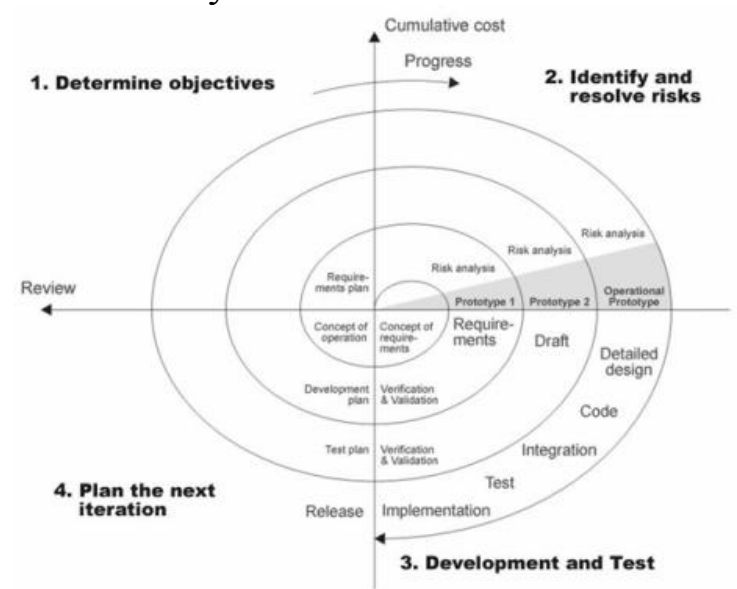

Gambar 1. Metode Spiral

\section{LANGKAH KERJA \\ PENGEMBANGAN SISTEM}

Berikut adalah langkah kerja dalam pengembangan sistem situs pendaftaran online peserta ujian mandiri Universitas Negeri Jakarta:

\section{Perencanaan (Planning)}

Pada tahap ini peneliti melakukan perencanaan untuk mengembangkan sistem dari segi database, user interface website, isi website, dan fungsi-fungsi tambahan yang diperlukan.

2. Analisis kebutuhan fungsional dan risiko (Risk Analysis)

Pada tahap ini, peneliti mengidentifikasi kebutuhan fungsional dan kemungkinan kesalahan yang terjadi pada sistem. Kebutuhan fungsional harus mendefinisikan aksi dasar yang diambil oleh sistem untuk menerima dan memproses input sehingga menghasilkan output, sedangkan analisis risiko mendefinisikan kemungkinan kesalahan yang terjadi pada sistem.

Pada tahap ini menghasilkan rancangan sebagai berikut: 


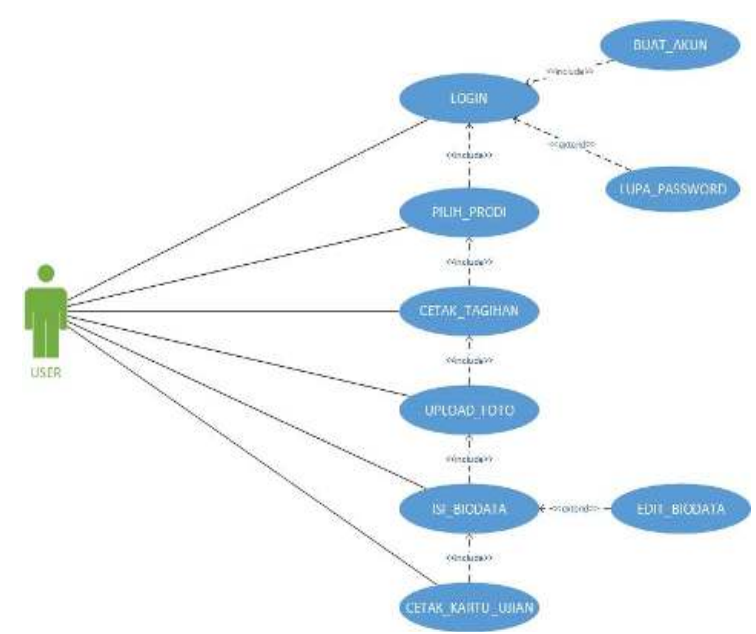

Gambar 2. Usecase Diagram Sistem

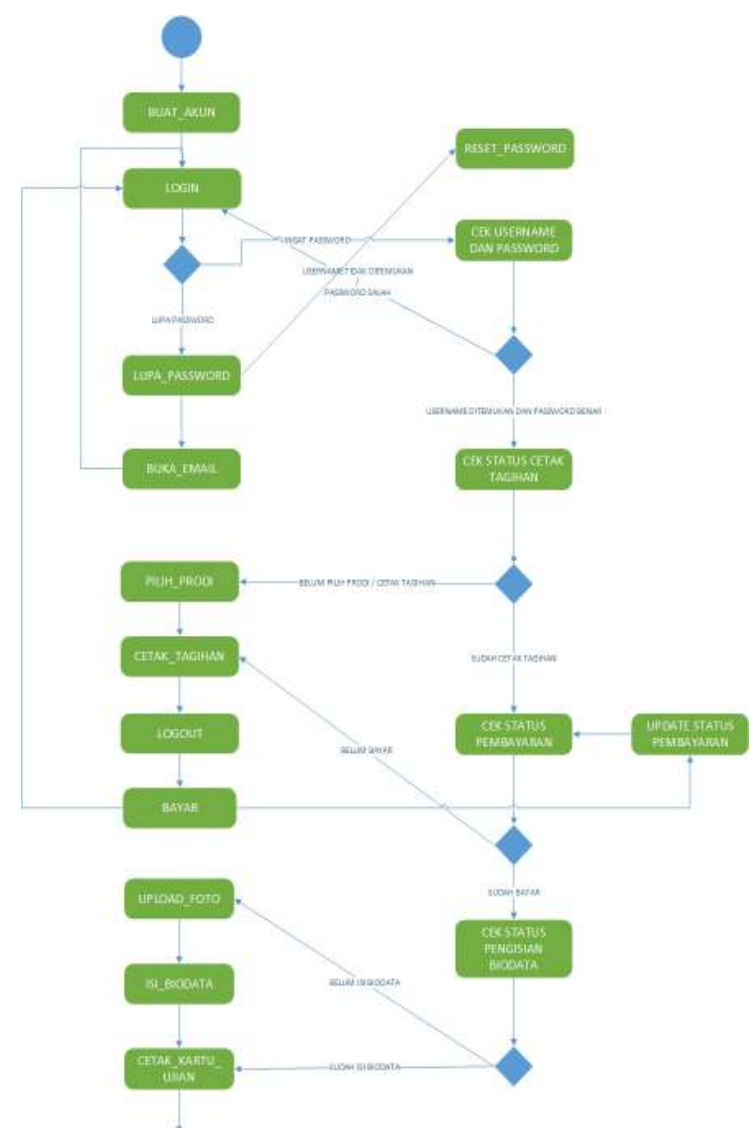

Gambar 3. Activity Diagram Sistem

\section{Rekayasa Sistem (Engineering)}

Dalam mengembangkan sistem dan evaluasi membutuhkan dukungan perangkat keras (hardware) dan perangkat lunak (software). Bahasa pemrograman yang digunakan adalah PHP, HTML, Javascript dan CSS (untuk logic controller dan user interface) serta MySQL (untuk database). Spesifikasi perangkat keras dan perangkat lunak yang digunakan pada pengembangan sistem situs pendaftaran online ujian mandiri di Universitas Negeri Jakarta adalah:

1. Perangkat Keras

Dalam penelitian ini digunakan sebuah laptop dengan spesifikasi sebagai berikut:

a. Windows 8.1 Professional 64bit, x64-based processor

b. Intel ${ }^{\circledR}$ Core $^{\mathrm{TM}}$ i5-3210M CPU (a) 2.50GHz (4CPUs), $\sim 2.5 \mathrm{GHz}$

c. $4096 \mathrm{MB}$ RAM

d. AMD Radeon HD 7670M

2. Perangkat Lunak

Perangkat lunak yang dipakai dalam penelitian ini antara lain:

a. NetBeans IDE 8.0

b. JDK 1.8.0 20

c. XAMPP 1.8.3-5

d. Apache 2.4.10

e. PHP 5.5.15

f. MySQL 5.6.20

g. PhpMyAdmin 4.2.7.1

4. Evaluasi Pemakai (Customer Evaluation)

Pengujian sistem menggunakan metode Black-box dengan teknik Feature test, yaitu pengujian yang digunakan untuk menguji fungsifungsi dari sistem yang dirancang. Pengujian ini dilakukan tanpa melihat source code sistem. Kebenaran sistem yang diuji dilihat berdasarkan keluaran sistem dan dinilai dengan mengacu pada kriteria keberhasilan program secara fungsional, sehingga jika terdapat kesalahan dari sistem dalam memenuhi kebutuhan pengguna (pendaftar) langsung dapat diketahui. Untuk penilaian berdasarkan kriteria berikut hasil pengujian dapat dilihat pada pembahasan selanjutnya di hasil penelitian. 
5. HASIL PENELITIAN

Penelitian memberikan hasil sebagai berikut:

Tabel 1. Pengujian Pengujian Fungsional pada Menu Index

\begin{tabular}{|c|c|c|c|}
\hline No. & Skenario & $\begin{array}{c}\text { Sistem } \\
\text { Bekerja }\end{array}$ & Ket \\
\hline 1. & $\begin{array}{l}\text { Hyperlink } \\
\text { ke halaman } \\
\text { pendaftaran } \\
\text { akun } \\
\text { berfungsi. }\end{array}$ & $\mathrm{Ya}$ & - \\
\hline 2. & $\begin{array}{l}\text { Hyperlink } \\
\text { ke halaman } \\
\text { pengiriman } \\
\text { email untuk } \\
\text { fitur lupa } \\
\text { password } \\
\text { berfungsi. }\end{array}$ & $\mathrm{Ya}$ & - \\
\hline 3. & $\begin{array}{l}\text { Textfield } \\
\text { untuk input } \\
\text { username } \\
\text { dan } \\
\text { password } \\
\text { berfungsi. }\end{array}$ & $\mathrm{Ya}$ & - \\
\hline 4. & $\begin{array}{l}\text { Button } \\
\text { Login } \\
\text { berfungsi. }\end{array}$ & $\mathrm{Ya}$ & - \\
\hline 5. & $\begin{array}{l}\text { Pesan } \\
\text { pemberitah } \\
\text { uan muncul } \\
\text { dan } \text { user } \\
\text { dapat } \\
\text { melakukan } \\
\text { login } \\
\text { setelah } \\
\text { menekan } \\
\text { button } \\
\text { Login. }\end{array}$ & $\mathrm{Ya}$ & 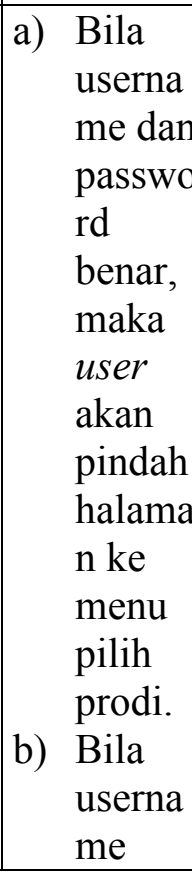 \\
\hline
\end{tabular}

\begin{tabular}{|l|l|l|}
\hline & & atau \\
& & passwo \\
rd \\
& salah, \\
& & maka \\
& user \\
& & tidak \\
& dapat \\
& & pindah \\
& halama \\
& n ke \\
& menu \\
& & pilih \\
& & prodi. \\
\hline
\end{tabular}

Tabel 2. Pengujian Fungsional pada Menu Pendaftaran Akun

\begin{tabular}{|c|l|c|c|}
\hline No. & $\begin{array}{l}\text { Skenario } \\
\text { Proses }\end{array}$ & $\begin{array}{c}\text { Sistem } \\
\text { Bekerja }\end{array}$ & Ket \\
\hline 1. & $\begin{array}{l}\text { Hyperlink } \\
\text { ke halaman } \\
\text { index } \\
\text { berfungsi. }\end{array}$ & Ya & - \\
\hline 2. & $\begin{array}{l}\text { Fitur live- } \\
\text { check } \\
\text { username } \\
\text { untuk } \\
\text { mendeteksi } \\
\text { duplikasi } \\
\text { username } \\
\text { di halaman } \\
\text { pendaftaran } \\
\text { akun } \\
\text { berfungsi } \\
\text { dengan } \\
\text { benar. }\end{array}$ & $\begin{array}{l}\text { Tampil } \\
\text { pemberitahuan } \\
\text { apakah } \\
\text { username } \\
\text { yang akan } \\
\text { didaftarkan } \\
\text { tersedia atau } \\
\text { tidak. }\end{array}$ \\
\hline 3. & $\begin{array}{l}\text { Fitur } \\
\text { Captcha } \\
\text { pada } \\
\text { halaman } \\
\text { pendaftaran } \\
\text { akun } \\
\text { tampil. }\end{array}$ & $\begin{array}{l}\text { Ya } \\
\text { Button } \\
\text { Daftar } \\
\text { tidak dapat } \\
\text { apakan } \\
\text { calon user } \\
\text { belum } \\
\text { mengisi }\end{array}$ & Ya \\
\hline \\
\end{tabular}




\begin{tabular}{|c|c|c|c|c|}
\hline & $\begin{array}{l}\text { semua } \\
\text { textfield } \\
\text { input yang } \\
\text { tersedia. }\end{array}$ & & & \\
\hline 5. & $\begin{array}{l}\text { Calon user } \\
\text { dapat } \\
\text { mengisi } \\
\text { semua } \\
\text { textfield } \\
\text { input yang } \\
\text { tersedia. }\end{array}$ & $\mathrm{Ya}$ & & - \\
\hline 6. & $\begin{array}{l}\text { Button } \\
\text { Daftar } \\
\text { dapat } \\
\text { ditekan } \\
\text { setelah } \\
\text { calon user } \\
\text { mengisi } \\
\text { semua } \\
\text { textfield } \\
\text { input yang } \\
\text { tersedia. }\end{array}$ & $\mathrm{Ya}$ & & - \\
\hline 7. & $\begin{array}{l}\text { Calon user } \\
\text { dapat } \\
\text { melakukan } \\
\text { pendaftaran } \\
\text { akun } \\
\text { setelah } \\
\text { menekan } \\
\text { button } \\
\text { Daftar. }\end{array}$ & $\mathrm{Ya}$ & a) & $\begin{array}{l}\text { Apabila } \\
\text { semua } \\
\text { input valid, } \\
\text { maka akun } \\
\text { peserta } \\
\text { berhasil } \\
\text { dibuat. } \\
\text { Apabila } \\
\text { semua } \\
\text { input tidak } \\
\text { valid, } \\
\text { maka akun } \\
\text { peserta } \\
\text { gagal } \\
\text { dibuat. }\end{array}$ \\
\hline
\end{tabular}

Tabel 3. Pengujian Fungsional pada Menu Lupa Password

\begin{tabular}{|c|l|c|c|}
\hline No. & Skenario Proses & $\begin{array}{c}\text { Sistem } \\
\text { Bekerja } \\
(\text { Ya/Tidak)* }\end{array}$ & Ket \\
\hline 1. & $\begin{array}{l}\text { Hyperlink ke } \\
\text { halaman } \\
\text { pendaftaran akun } \\
\text { berfungsi. }\end{array}$ & Ya & \\
\hline 2. & $\begin{array}{l}\text { Textfield untuk } \\
\text { input username } \\
\text { berfungsi. }\end{array}$ & Ya & - \\
\hline 3. & Button Daftar & Ya & - \\
\hline
\end{tabular}

\begin{tabular}{|c|c|c|c|}
\hline & 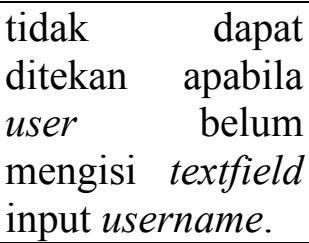 & & \\
\hline 4. & $\begin{array}{lr}\text { Button } & \text { Daftar } \\
\text { dapat } & \text { ditekan } \\
\text { setelah } & \text { user } \\
\text { mengisi } & \text { textfield } \\
\text { input } & \text { username. }\end{array}$ & $\mathrm{Ya}$ & - \\
\hline 5. & $\begin{array}{l}\text { Pesan } \\
\text { pemberitahuan } \\
\text { muncul setelah } \\
\text { user menekan } \\
\text { button Kirim. }\end{array}$ & $\mathrm{Ya}$ & - \\
\hline
\end{tabular}

Tabel 4. Pengujian Fungsional pada Menu Pemilihan Kelompok Ujian dan Program Studi

\begin{tabular}{|c|c|c|c|}
\hline No. & Skenario Proses & $\begin{array}{c}\text { Sistem } \\
\text { Bekerja } \\
(\text { Ya/Tidak) })^{*}\end{array}$ & Ket \\
\hline 1. & $\begin{array}{l}\text { Progress } \\
\text { Indicator berada } \\
\text { pada Pilih Prodi. }\end{array}$ & $\mathrm{Ya}$ & - \\
\hline 2. & $\begin{array}{l}\text { Option Selector } \\
\text { Kelompok Ujian } \\
\text { berfungsi dengan } \\
\text { benar. }\end{array}$ & Ya & - \\
\hline 3. & $\begin{array}{lr}\text { Selector } & \text { Pilihan } \\
\text { Program Studi 1 } & \text { Stumpilkan } \\
\text { menampin } & \\
\text { Program } & \text { Studi } \\
\text { bidang } & \text { IPA } \\
\text { apabila } & \text { user } \\
\text { memilih } & \\
\text { kelompok } & \text { ujian } \\
\text { IPA. } & \end{array}$ & $\mathrm{Ya}$ & - \\
\hline 4. & $\begin{array}{lr}\text { Selector } & \text { Pilihan } \\
\text { Program Studi } 2 \\
\text { menampilkan } \\
\text { Program } & \text { Studi } \\
\text { bidang } & \text { IPA } \\
\text { selain } & \text { Program } \\
\text { Studi yang telah } \\
\text { dipilih user pada } \\
\text { Selector Pilihan } \\
\text { Program Studi } 1 \\
\text { apabila }\end{array}$ & $\mathrm{Ya}$ & - \\
\hline
\end{tabular}




\begin{tabular}{|c|c|c|c|}
\hline & $\begin{array}{l}\text { memilih } \\
\text { kelompok ujian } \\
\text { IPA. }\end{array}$ & & \\
\hline 5. & $\begin{array}{lr}\text { Selector } & \text { Pilihan } \\
\text { Program } & \text { Studi } 1 \\
\text { menampilkan } \\
\text { Program } & \text { Studi } \\
\text { bidang } & \text { IPS } \\
\text { apabila } & \text { user } \\
\text { memilih } & \\
\text { kelompok } & \text { ujian } \\
\text { IPS. } & \\
\end{array}$ & $\mathrm{Ya}$ & - \\
\hline 6. & $\begin{array}{lr}\text { Selector } & \text { Pilihan } \\
\text { Program Studi } 2 \\
\text { menampilkan } \\
\text { Program Studi } \\
\text { bidang IPS } & \text { selain } \\
\text { Program Studi } \\
\text { yang telah dipilih } \\
\text { user } \\
\text { Selector Pilihan } \\
\text { Program } \\
\text { apabila Studi } 1 \\
\text { memilih } \\
\text { kelompok user } \\
\text { IPS. }\end{array}$ & $\mathrm{Ya}$ & - \\
\hline 7. & $\begin{array}{l}\text { Selector Pilihan } \\
\text { Program Studi } 1 \\
\text { menampilkan } \\
\text { Program Studi } \\
\text { bidang Alih } \\
\text { Program apabila } \\
\text { user memilih } \\
\text { kelompok ujian } \\
\text { Alih Program. }\end{array}$ & $\mathrm{Ya}$ & - \\
\hline 8. & $\begin{array}{lr}\text { Selector } & \text { Pilihan } \\
\text { Program } & \text { Studi } 2 \\
\text { menampilkan } \\
\text { Program } & \text { Studi } \\
\text { bidang } & \text { Alih } \\
\text { Program } & \text { selain } \\
\text { Program } & \text { Studi } \\
\text { yang telah dipilih } \\
\text { user } & \text { pada } \\
\text { Selector } & \text { Pilihan } \\
\text { Program } & \text { Studi 1 } \\
\text { apabila } & \text { user } \\
\text { memilih } & \\
\text { kelompok } & \text { ujian }\end{array}$ & $\mathrm{Ya}$ & - \\
\hline
\end{tabular}

\begin{tabular}{|c|c|c|c|}
\hline & Alih Program. & & \\
\hline 9. & $\begin{array}{l}\text { Selector Pilihan } \\
\text { Program Studi 1 } \\
\text { menampilkan } \\
\text { Program Studi } \\
\text { bidang IPA dan } \\
\text { IPS apabila user } \\
\text { memilih } \\
\text { kelompok ujian } \\
\text { IPC. }\end{array}$ & $\mathrm{Ya}$ & - \\
\hline 10. & $\begin{array}{lr}\text { Selector } & \text { Pilihan } \\
\text { Program } & \text { Studi } 2 \\
\text { menampilkan } \\
\text { Program Studi } \\
\text { bidang IPA dan } \\
\text { IPS } & \text { selain } \\
\text { Program } & \text { Studi } \\
\text { yang telah dipilih } \\
\text { user rer pada } \\
\text { Selector Pilihan } \\
\text { Program } & \text { Studi 1 } \\
\text { apabila } & \text { user } \\
\text { memilih } & \\
\text { kelompok ujian } \\
\text { IPC. }\end{array}$ & $\mathrm{Ya}$ & - \\
\hline 11. & $\begin{array}{lr}\text { Selector } & \text { Pilihan } \\
\text { Program } & \text { Studi } 3 \\
\text { menampilkan } \\
\text { Program } & \text { Studi } \\
\text { bidang } & \text { IPA dan } \\
\text { IPS } & \text { selain } \\
\text { Program } & \text { Studi } \\
\text { yang telah dipilih } \\
\text { user } & \text { pada } \\
\text { Selector } & \text { Pilihan } \\
\text { Program } & \text { Studi } 1 \\
\text { dan } & \text { Selector } \\
\text { Pilihan } & \text { Program } \\
\text { Studi 2 } & \text { apabila } \\
\text { user } & \text { memilih } \\
\text { kelompok } & \text { ujian } \\
\text { IPC. } & \\
\end{array}$ & $\mathrm{Ya}$ & - \\
\hline 12. & $\begin{array}{lr}\text { Selector } & \text { Pilihan } \\
\text { Program } & \text { Studi 1 } \\
\text { dan } & \text { Pilihan } \\
\text { Program } & \text { Studi 2 } \\
\text { muncul apabila } \\
\text { user memilih } \\
\text { Kelompok Ujian } \\
\text { IPA, IPS, atau } \\
\text { Alih Program. }\end{array}$ & $\mathrm{Ya}$ & - \\
\hline
\end{tabular}




\begin{tabular}{|c|c|c|c|}
\hline 13. & $\begin{array}{l}\text { Selector } \\
\text { Program Studi 1, } \\
\text { Pilihan Program } \\
\text { Studi } 2, \quad \text { dan } \\
\text { Pilihan Prodi } 3 \\
\text { muncul apabila } \\
\text { user memilih } \\
\text { Kelompok Ujian } \\
\text { IPC. }\end{array}$ & $\mathrm{Ya}$ & - \\
\hline 14. & $\begin{array}{lr}\text { Total } & \text { Biaya } \\
\text { muncul } & \text { setelah } \\
\text { user } & \text { mengisi } \\
\text { semua } & \text { selector } \\
\text { pilihan } & \text { program } \\
\text { studi } & \text { dengan } \\
\text { nominal } & \text { sesuai } \\
\text { yang } & \text { telah } \\
\text { ditentukan. } & \\
\end{array}$ & $\mathrm{Ya}$ & - \\
\hline 15. & $\begin{array}{l}\text { Button Lanjutkan } \\
\text { tidak dapat } \\
\text { ditekan apabila } \\
\text { Dislaimer option } \\
\text { belum diisi. }\end{array}$ & $\mathrm{Ya}$ & - \\
\hline 16. & $\begin{array}{l}\text { Disclaimer } \\
\text { option berfungsi } \\
\text { dengan benar. }\end{array}$ & $\mathrm{Ya}$ & - \\
\hline 17. & $\begin{array}{l}\text { Button Lanjutkan } \\
\text { dapat ditekan } \\
\text { apabila Dislaimer } \\
\text { option telah diisi. }\end{array}$ & $\mathrm{Ya}$ & - \\
\hline 18. & $\begin{array}{lr}\text { User } & \text { dapat } \\
\text { pindah } & \text { ke } \\
\text { halaman } & \text { review } \\
\text { kelompok } & \text { ujian } \\
\text { dan } & \text { program } \\
\text { studi } & \text { setelah } \\
\text { menekan } & \text { button } \\
\text { Lanjutkan } & \end{array}$ & $\mathrm{Ya}$ & - \\
\hline
\end{tabular}

Tabel 5. Pengujian Fungsional pada Menu Review Kelompok Ujian dan Program Studi

\begin{tabular}{|c|l|c|c|}
\hline No. & Skenario Proses & $\begin{array}{c}\text { Sistem } \\
\text { Bekerja } \\
\text { (Ya/Tidak)* }\end{array}$ & Ket \\
\hline 1. & $\begin{array}{l}\text { Progress } \\
\text { Indicator berada } \\
\text { pada Cetak } \\
\text { Tagihan. }\end{array}$ & Ya & - \\
\hline 2. & $\begin{array}{l}\text { Halaman } \\
\text { menampilkan }\end{array}$ & Ya & - \\
\hline
\end{tabular}

\begin{tabular}{|c|c|c|c|}
\hline & $\begin{array}{l}\text { Kelompok Ujian, } \\
\text { Pilihan Program } \\
\text { Studi, dan Total } \\
\text { Biaya dengan } \\
\text { benar sesuai } \\
\text { dengan pilihan } \\
\text { user. }\end{array}$ & & \\
\hline 3. & $\begin{array}{lr}\text { User } & \text { dapat } \\
\text { pindah } & \text { ke } \\
\text { halaman } & \\
\text { pemilihan } & \\
\text { kelompok } & \text { ujian } \\
\text { dan program } \\
\text { studi } & \text { apabila } \\
\text { menekan } & \text { button } \\
\text { Kembali r dan } \\
\text { melakukan } \\
\text { pemilihan ulang. }\end{array}$ & $\mathrm{Ya}$ & - \\
\hline 4. & $\begin{array}{l}\text { Pesan } \\
\text { pemberitahuan } \\
\text { muncul dan user } \\
\text { dapat pindah ke } \\
\text { halaman cetak } \\
\text { tagihan apabila } \\
\text { menekan button } \\
\text { Cetak Tagihan. }\end{array}$ & $\mathrm{Ya}$ & - \\
\hline
\end{tabular}

Tabel 6. Pengujian Fungsional pada Menu Cetak Tagihan

\begin{tabular}{|c|l|c|c|}
\hline No. & Skenario Proses & $\begin{array}{c}\text { Sistem } \\
\text { Bekerja } \\
\text { (Ya/Tidak)* }\end{array}$ & Ket \\
\hline 1. & $\begin{array}{l}\text { Progress } \\
\text { Indicator berada } \\
\text { pada Cetak } \\
\text { Tagihan. }\end{array}$ & Ya & \\
\hline 2. & $\begin{array}{l}\text { Halaman } \\
\text { menampilkan } \\
\text { Kelompok Ujian, } \\
\text { Pilihan Program } \\
\text { Studi, Total } \\
\text { Biaya, dan } \\
\text { Tanggal } \\
\text { Kadaluarsa } \\
\text { Tagihan dengan } \\
\text { benar sesuai } \\
\text { dengan pilihan } \\
\text { user. }\end{array}$ & Ya & \\
\hline 3. & $\begin{array}{l}\text { User dapat } \\
\text { membuka } \\
\text { halaman yang }\end{array}$ & Ya & - \\
\hline
\end{tabular}




\begin{tabular}{|l|l|l|}
\hline menampilkan & & \\
rincian tagihan di & & \\
tab baru pada & & \\
apabila menekan & & \\
button Cetak & & \\
Tagihan. & & \\
\hline
\end{tabular}

Tabel 7. Pengujian Fungsional pada Menu Upload Foto

\begin{tabular}{|c|c|c|c|}
\hline No. & Skenario Proses & $\begin{array}{c}\text { Sistem } \\
\text { Bekerja } \\
(\text { Ya/Tidak })^{*}\end{array}$ & Ket \\
\hline 1. & $\begin{array}{ll}\text { Progress } & \\
\text { Indicator berada } \\
\text { pada } & \text { Upload } \\
\text { Foto. } & \end{array}$ & $\mathrm{Ya}$ & - \\
\hline 2. & $\begin{array}{l}\text { File Uploader } \\
\text { berfungsi dengan } \\
\text { benar. }\end{array}$ & $\mathrm{Ya}$ & - \\
\hline 3. & $\begin{array}{lr}\text { Sistem } & \text { akan } \\
\text { menolak } & \text { dan } \\
\text { akan muncul } & \text { pesan peringatan } \\
\text { apabila file foto } \\
\text { yang diunggah } \\
\text { tidak dalam } \\
\text { format .jpg. }\end{array}$ & $\mathrm{Ya}$ & - \\
\hline 4. & $\begin{array}{l}\text { Submit icon, } \\
\text { Cancel } \\
\text { Zoom In icon, } \\
\text { Zoom Out icon, } \\
\text { Move Up icon, } \\
\text { Move Down icon, } \\
\text { Move Right icon, } \\
\text { dan Move Left } \\
\text { icon muncul } \\
\text { setelah user } \\
\text { mengunggah } \\
\text { foto. }\end{array}$ & $\mathrm{Ya}$ & - \\
\hline 5. & $\begin{array}{lr}\text { Submit Icon } \\
\text { berfungsi dengan } \\
\text { benar. }\end{array}$ & $\mathrm{Ya}$ & - \\
\hline 6. & $\begin{array}{l}\text { Cancel Icon } \\
\text { berfungsi dengan } \\
\text { benar. }\end{array}$ & $\mathrm{Ya}$ & - \\
\hline 7. & $\begin{array}{l}\text { Zoom In Icon } \\
\text { berfungsi dengan } \\
\text { benar. }\end{array}$ & $\mathrm{Ya}$ & - \\
\hline 8. & $\begin{array}{l}\text { Zoom Out Icon } \\
\text { berfungsi dengan } \\
\text { benar. }\end{array}$ & $\mathrm{Ya}$ & - \\
\hline
\end{tabular}

\begin{tabular}{|c|c|c|c|}
\hline 9. & $\begin{array}{l}\text { Move Up Icon } \\
\text { berfungsi dengan } \\
\text { benar. }\end{array}$ & $\mathrm{Ya}$ & - \\
\hline 10. & $\begin{array}{l}\text { Move Down Icon } \\
\text { berfungsi dengan } \\
\text { benar. }\end{array}$ & $\mathrm{Ya}$ & - \\
\hline 11. & $\begin{array}{l}\text { Move Right Icon } \\
\text { berfungsi dengan } \\
\text { benar. }\end{array}$ & $\mathrm{Ya}$ & - \\
\hline 12 . & $\begin{array}{l}\text { Move Left Icon } \\
\text { berfungsi dengan } \\
\text { benar. }\end{array}$ & $\mathrm{Ya}$ & - \\
\hline 13. & $\begin{array}{lr}\text { Submit } & \text { icon, } \\
\text { Cancel } & \text { icon, } \\
\text { Zoom In icon, } \\
\text { Zoom Out icon, } \\
\text { Move Up icon, } \\
\text { Move Down icon, } \\
\text { Move Right icon, } \\
\text { dan Move Left } \\
\text { icon hilang } \\
\text { setelah user } \\
\text { menekan Submit } \\
\text { icon. }\end{array}$ & $\mathrm{Ya}$ & - \\
\hline 14. & $\begin{array}{l}\text { Button Upload } \\
\text { dan button Batal } \\
\text { muncul setelah } \\
\text { user menekan } \\
\text { Submit icon. }\end{array}$ & $\mathrm{Ya}$ & - \\
\hline 15. & $\begin{array}{l}\text { File Uploader } \\
\text { muncul apabila } \\
\text { user menekan } \\
\text { button Batal dan } \\
\text { user akan } \\
\text { melakukan } \\
\text { proses unggah } \\
\text { foto dari awal. }\end{array}$ & $\mathrm{Ya}$ & - \\
\hline 16. & $\begin{array}{l}\text { User pindah ke } \\
\text { halaman } \\
\text { pengisian biodata } \\
\text { apabila menekan } \\
\text { button Upload. }\end{array}$ & $\mathrm{Ya}$ & - \\
\hline
\end{tabular}

Tabel 8. Pengujian Fungsional pada Menu Pengisian Biodata

\begin{tabular}{|c|l|c|c|}
\hline No. & Skenario Proses & $\begin{array}{c}\text { Sistem } \\
\text { Bekerja } \\
\text { (Ya/Tidak)* }\end{array}$ & Ket \\
\hline 1. & $\begin{array}{l}\text { Progress } \\
\text { Indicator berada } \\
\text { pada Biodata. }\end{array}$ & Ya & - \\
\hline
\end{tabular}




\begin{tabular}{|c|c|c|c|}
\hline 2. & $\begin{array}{l}\text { Semua textfield } \\
\text { dapat diisi. }\end{array}$ & $\mathrm{Ya}$ & - \\
\hline 3. & $\begin{array}{ll}\text { Option } & \text { Selector } \\
\text { Jenis Identitas } \\
\text { berfungsi dengan } \\
\text { benar. }\end{array}$ & $\mathrm{Ya}$ & - \\
\hline 4. & $\begin{array}{l}\text { Option Selector } \\
\text { Kewarganegaraan } \\
\text { berfungsi dengan } \\
\text { benar. }\end{array}$ & $\mathrm{Ya}$ & - \\
\hline 5. & $\begin{array}{ll}\text { Option } & \text { Selector } \\
\text { Jenis } & \text { Kelamin } \\
\text { berfungsi dengan } \\
\text { benar. }\end{array}$ & $\mathrm{Ya}$ & - \\
\hline 6. & $\begin{array}{l}\text { Option Selector } \\
\text { Provinsi } \\
\text { berfungsi dengan } \\
\text { benar. }\end{array}$ & $\mathrm{Ya}$ & - \\
\hline 7. & $\begin{array}{l}\text { Option Selector } \\
\text { Kabupaten/Kota } \\
\text { berfungsi dengan } \\
\text { benar dan } \\
\text { menampilkan } \\
\text { Kabupaten/Kota } \\
\text { sesuai dengan } \\
\text { Provinsi yang } \\
\text { dipilih user pada } \\
\text { Option Selector } \\
\text { Provinsi. }\end{array}$ & $\mathrm{Ya}$ & - \\
\hline 8. & $\begin{array}{l}\text { Option Selector } \\
\text { Agama berfungsi } \\
\text { dengan benar. }\end{array}$ & $\mathrm{Ya}$ & - \\
\hline 9. & $\begin{array}{l}\text { Option Selector } \\
\text { Pekerjaan Ayah } \\
\text { berfungsi dengan } \\
\text { benar. }\end{array}$ & $\mathrm{Ya}$ & - \\
\hline 10. & $\begin{array}{l}\text { Option Selector } \\
\text { Pekerjaan Ibu } \\
\text { berfungsi dengan } \\
\text { benar. }\end{array}$ & $\mathrm{Ya}$ & - \\
\hline 11. & $\begin{array}{l}\text { Option Selector } \\
\text { Penghasilan } \\
\text { Ayah berfungsi } \\
\text { dengan benar. }\end{array}$ & $\mathrm{Ya}$ & - \\
\hline 12. & $\begin{array}{l}\text { Option Selector } \\
\text { Penghasilan Ibu } \\
\text { berfungsi dengan } \\
\text { benar. }\end{array}$ & $\mathrm{Ya}$ & - \\
\hline 13. & $\begin{array}{l}\text { Option Selector } \\
\text { Jumlah } \\
\text { Tanggungan }\end{array}$ & $\mathrm{Ya}$ & - \\
\hline
\end{tabular}

\begin{tabular}{|c|c|c|c|}
\hline & $\begin{array}{l}\text { berfungsi dengan } \\
\text { benar. }\end{array}$ & & \\
\hline 14. & $\begin{array}{l}\text { Option Selector } \\
\text { Jenis Pendidikan } \\
\text { berfungsi dengan } \\
\text { benar. }\end{array}$ & $\mathrm{Ya}$ & - \\
\hline 15. & $\begin{array}{l}\text { Option Selector } \\
\text { Jurusan/Bidang } \\
\text { berfungsi dengan } \\
\text { benar. }\end{array}$ & $\mathrm{Ya}$ & - \\
\hline 16. & $\begin{array}{l}\text { Fitur Date-Picker } \\
\text { berfungsi dengan } \\
\text { benar. }\end{array}$ & $\mathrm{Ya}$ & - \\
\hline 17. & $\begin{array}{lr}\text { User pindah ke } \\
\text { halaman review } \\
\text { biodata apabila } \\
\text { menekan button } \\
\text { Preview. }\end{array}$ & $\mathrm{Ya}$ & - \\
\hline
\end{tabular}

Tabel 9. Pengujian Fungsional pada Menu Review Biodata

\begin{tabular}{|c|c|c|c|}
\hline No. & Skenario Proses & $\begin{array}{c}\text { Sistem } \\
\text { Bekerja } \\
(\mathrm{Ya} / \text { Tidak })^{*}\end{array}$ & Ket \\
\hline 1. & $\begin{array}{l}\text { Progress } \\
\text { Indicator berada } \\
\text { pada Biodata. }\end{array}$ & $\mathrm{Ya}$ & - \\
\hline 2. & $\begin{array}{l}\text { Halaman } \\
\text { menampilkan } \\
\text { seluruh data yang } \\
\text { telah diisi pada } \\
\text { halaman } \\
\text { pengisian biodata } \\
\text { serta foto yang } \\
\text { diunggah di } \\
\text { halaman upload } \\
\text { foto. }\end{array}$ & $\mathrm{Ya}$ & - \\
\hline 3. & $\begin{array}{lr}\text { Semua } & \text { tampilan } \\
\text { input } & \text { berubah } \\
\text { menjadi } & \text { label, } \\
\text { serta } & \text { muncul } \\
\text { button } & \text { Batal dan } \\
\text { button } & \text { Simpan } \\
\text { setelah } & \text { user } \\
\text { menekan } & \text { button } \\
\text { Lanjutkan. }\end{array}$ & $\mathrm{Ya}$ & - \\
\hline 4. & $\begin{array}{l}\text { User kembali ke } \\
\text { halaman upload } \\
\text { foto apabila } \\
\text { menekan button } \\
\text { Batal. }\end{array}$ & $\mathrm{Ya}$ & - \\
\hline
\end{tabular}




\begin{tabular}{|l|l|l|l|}
\hline 5. & $\begin{array}{l}\text { Pemberitahuan } \\
\text { muncul dan user }\end{array}$ & & \\
dapat membuka & & \\
halaman yang & & \\
menampilkan & & \\
kartu ujian di tab & & \\
baru pada & & \\
browser apabila & & \\
menekan button & & \\
Simpan. & & \\
\hline
\end{tabular}

Tabel 10. Pengujian Fungsional pada Menu Tampilan Biodata

\begin{tabular}{|c|c|c|c|}
\hline No. & $\begin{array}{c}\text { Skenario } \\
\text { Proses }\end{array}$ & $\begin{array}{c}\text { Sistem } \\
\text { Bekerja } \\
(\text { Ya/Tidak)* }\end{array}$ & Ket \\
\hline 1. & $\begin{array}{l}\text { Progress } \\
\text { Indicator } \\
\text { berada pada } \\
\text { Cetak Kartu. }\end{array}$ & $\mathrm{Ya}$ & - \\
\hline 2. & $\begin{array}{l}\text { Halaman } \\
\text { menampilkan } \\
\text { seluruh data } \\
\text { yang telah } \\
\text { diisi pada } \\
\text { halaman } \\
\text { pengisian } \\
\text { biodata, foto } \\
\text { yang diunggah } \\
\text { di halaman } \\
\text { upload foto, } \\
\text { serta pilihan } \\
\text { kelompok } \\
\text { ujian dan } \\
\text { pilihan } \\
\text { program studi } \\
\text { dengan benar } \\
\text { sesuai pilihan } \\
\text { user. }\end{array}$ & $\mathrm{Ya}$ & - \\
\hline 3. & $\begin{array}{l}\text { User pindah } \\
\text { ke halaman } \\
\text { edit biodata } \\
\text { apabila } \\
\text { menekan } \\
\text { button Edit. }\end{array}$ & $\mathrm{Ya}$ & $\begin{array}{l}\text { Button } \\
\text { Edit } \\
\text { tidak } \\
\text { tampil } \\
\text { apabila } \\
\text { user } \\
\text { sudah } \\
\text { mencetak } \\
\text { kartu } \\
\text { ujian. }\end{array}$ \\
\hline 4. & $\begin{array}{l}\text { Pesan } \\
\text { pemberitahuan }\end{array}$ & $\mathrm{Ya}$ & - \\
\hline
\end{tabular}

\begin{tabular}{|l|l|l|}
\hline muncul dan & & \\
user rapat & & \\
pindah r ke & & \\
halaman cetak & & \\
kartu apabila & & \\
menekan & & \\
button Cetak & & \\
Kartu. & & \\
\hline
\end{tabular}

Tabel 11. Pengujian Fungsional pada Menu Edit Biodata

\begin{tabular}{|c|c|c|c|}
\hline No. & Skenario Proses & $\begin{array}{c}\text { Sistem } \\
\text { Bekerja } \\
(\mathrm{Ya} / \text { Tidak })^{*}\end{array}$ & Ket \\
\hline 1. & $\begin{array}{l}\text { Progress } \\
\text { Indicator berada } \\
\text { pada Biodata. }\end{array}$ & $\mathrm{Ya}$ & - \\
\hline 2. & $\begin{array}{l}\text { Semua textfield } \\
\text { dapat diisi. }\end{array}$ & $\mathrm{Ya}$ & - \\
\hline 3. & $\begin{array}{ll}\text { Option } & \text { Selector } \\
\text { Jenis } & \text { Identitas } \\
\text { berfungsi dengan } \\
\text { benar. }\end{array}$ & $\mathrm{Ya}$ & - \\
\hline 4. & $\begin{array}{l}\text { Option Selector } \\
\text { Kewarganegaraan } \\
\text { berfungsi dengan } \\
\text { benar. }\end{array}$ & $\mathrm{Ya}$ & - \\
\hline 5. & $\begin{array}{l}\text { Option Selector } \\
\text { Jenis Kelamin } \\
\text { berfungsi dengan } \\
\text { benar. }\end{array}$ & $\mathrm{Ya}$ & - \\
\hline 6. & $\begin{array}{l}\text { Option Selector } \\
\text { Provinsi } \\
\text { berfungsi dengan } \\
\text { benar. }\end{array}$ & $\mathrm{Ya}$ & - \\
\hline 7. & $\begin{array}{l}\text { Option Selector } \\
\text { Kabupaten/Kota } \\
\text { berfungsi dengan } \\
\text { benar dan } \\
\text { menampilkan } \\
\text { Kabupaten/Kota } \\
\text { sesuai dengan } \\
\text { Provinsi yang } \\
\text { dipilih user pada } \\
\text { Option Selector } \\
\text { Provinsi. }\end{array}$ & $\mathrm{Ya}$ & - \\
\hline 8. & $\begin{array}{l}\text { Option Selector } \\
\text { Agama berfungsi } \\
\text { dengan benar. }\end{array}$ & $\mathrm{Ya}$ & - \\
\hline 9. & $\begin{array}{l}\text { Option Selector } \\
\text { Pekerjaan Ayah }\end{array}$ & Ya & - \\
\hline
\end{tabular}




\begin{tabular}{|c|c|c|c|}
\hline & $\begin{array}{l}\text { berfungsi dengan } \\
\text { benar. }\end{array}$ & & \\
\hline 10 & $\begin{array}{l}\text { Option Selector } \\
\text { Pekerjaan Ibu } \\
\text { berfungsi dengan } \\
\text { benar. }\end{array}$ & $\mathrm{Ya}$ & - \\
\hline 11. & $\begin{array}{l}\text { Option Selector } \\
\text { Penghasilan } \\
\text { Ayah berfungsi } \\
\text { dengan benar. }\end{array}$ & $\mathrm{Ya}$ & - \\
\hline 12 & $\begin{array}{l}\text { Option Selector } \\
\text { Penghasilan Ibu } \\
\text { berfungsi dengan } \\
\text { benar. }\end{array}$ & $\mathrm{Ya}$ & - \\
\hline 13. & $\begin{array}{l}\text { Option Selector } \\
\text { Jumlah } \\
\text { Tanggungan } \\
\text { berfungsi dengan } \\
\text { benar. }\end{array}$ & $\mathrm{Ya}$ & - \\
\hline 14. & $\begin{array}{l}\text { Option Selector } \\
\text { Jenis Pendidikan } \\
\text { berfungsi dengan } \\
\text { benar. }\end{array}$ & $\mathrm{Ya}$ & - \\
\hline 15. & $\begin{array}{l}\text { Option Selector } \\
\text { Jurusan/Bidang } \\
\text { berfungsi dengan } \\
\text { benar. }\end{array}$ & $\mathrm{Ya}$ & - \\
\hline 16. & $\begin{array}{l}\text { Fitur Date-Picker } \\
\text { berfungsi dengan } \\
\text { benar. }\end{array}$ & $\mathrm{Ya}$ & - \\
\hline 17. & $\begin{array}{l}\text { File Uploader } \\
\text { berfungsi dengan } \\
\text { benar. }\end{array}$ & $\mathrm{Ya}$ & - \\
\hline 18. & $\begin{array}{l}\text { Submit icon, } \\
\text { Cancel } \text { icon, } \\
\text { Zoom In icon, } \\
\text { Zoom Out icon, } \\
\text { Move Up icon, } \\
\text { Move Down icon, } \\
\text { Move Right icon, } \\
\text { dan Move Left } \\
\text { icon muncul } \\
\text { setelah user } \\
\text { mengunggah } \\
\text { foto. }\end{array}$ & $\mathrm{Ya}$ & - \\
\hline 19. & $\begin{array}{lr}\text { Submit } & \text { Icon } \\
\text { berfungsi dengan } \\
\text { benar. }\end{array}$ & $\mathrm{Ya}$ & - \\
\hline 20. & $\begin{array}{lr}\text { Cancel Icon } \\
\text { berfungsi dengan }\end{array}$ & $\mathrm{Ya}$ & - \\
\hline
\end{tabular}

\begin{tabular}{|c|c|c|c|}
\hline & benar. & & \\
\hline 21. & $\begin{array}{l}\text { Zoom In Icon } \\
\text { berfungsi dengan } \\
\text { benar. }\end{array}$ & $\mathrm{Ya}$ & - \\
\hline 22. & $\begin{array}{l}\text { Zoom Out Icon } \\
\text { berfungsi dengan } \\
\text { benar. }\end{array}$ & $\mathrm{Ya}$ & - \\
\hline 23. & $\begin{array}{l}\text { Move Up Icon } \\
\text { berfungsi dengan } \\
\text { benar. }\end{array}$ & $\mathrm{Ya}$ & - \\
\hline 24. & $\begin{array}{l}\text { Move Down Icon } \\
\text { berfungsi dengan } \\
\text { benar. }\end{array}$ & $\mathrm{Ya}$ & - \\
\hline 25. & $\begin{array}{l}\text { Move Right Icon } \\
\text { berfungsi dengan } \\
\text { benar. }\end{array}$ & $\mathrm{Ya}$ & - \\
\hline 26. & $\begin{array}{l}\text { Move Left Icon } \\
\text { berfungsi dengan } \\
\text { benar. }\end{array}$ & $\mathrm{Ya}$ & - \\
\hline 27. & 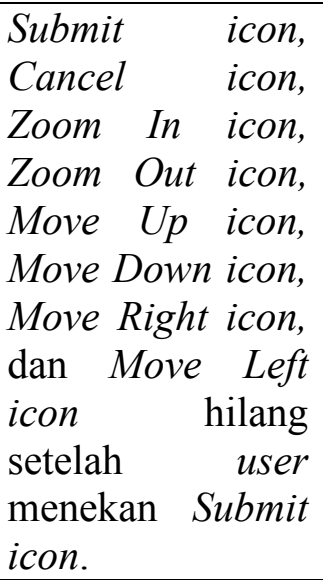 & $\mathrm{Ya}$ & - \\
\hline 28. & $\begin{array}{ll}\text { Button } & \text { Cancel } \\
\text { berfungsi } & \text { dengan } \\
\text { benar. } & \\
\end{array}$ & $\mathrm{Ya}$ & - \\
\hline 29. & $\begin{array}{l}\text { User kembali ke } \\
\text { halaman tampilan } \\
\text { biodata apabila } \\
\text { menekan button } \\
\text { Batal. }\end{array}$ & $\mathrm{Ya}$ & - \\
\hline 30. & $\begin{array}{l}\text { User pindah ke } \\
\text { halaman tampilan } \\
\text { biodata apabila } \\
\text { menekan button } \\
\text { Simpan. }\end{array}$ & $\mathrm{Ya}$ & - \\
\hline
\end{tabular}

\section{KESIMPULAN DAN SARAN}

Berdasarkan hasil pengujian menunjukkan bahwa sistem yang dirancang telah memenuhi spesifikasi yang diharapkan, sehingga dapat dikatakan bahwa aplikasi ini layak untuk dijadikan 
sebuah sistem pendaftaran peserta ujian secara online bagi perguruan tinggi yang hendak menyelenggarakan ujian mandiri. Untuk penelitian selanjutnya penulis mengharapkan adanya pengembangan untuk tampilan user interface yang lebih menarik baik dari segi warna, tulisan, tata letak, hingga navigasi untuk para pengguna. selain itu, dilakukan juga penelitian dalam menentukan rancangan dan struktur database yang lebih baik guna performa sistem yang lebih baik.

\section{DAFTAR PUSTAKA}

[1] Eriyatno. 2003. Ilmu Sistem Meningkatkan Mutu dan Efektifitas Manajemen. Bogor: IPB Press.

[2] Burch Jr, John G. Et al. 1979. Information System, Theory and Practice 2nd ed, USA: John Willey and Sons Inc.
[3] Al Fatta, Hanif. 2007. Analisis dan Perancangan Sistem Informasi. Yogyakarta: Andi.

[4] Kadir, Abdul. 2003. Pengenalan Sistem Informasi. Yogyakarta: ANDI.

[5] Pressman, Roger S. 1992. Software Engineering: A Practicioner's Approach, Seventh Edition. New York: McGrawHill.

[6] Satzinger, J. W., Jackson, R. B., \& Burd, S. D. (2010). System Analysis And Design in A Changing World. Boston, MA: Course Technology.

[7] Penerimaan Mahasiswa Baru Universitas Negeri Jakarta. http://penmaba.unj.ac.id $\quad[17 \quad$ Mei 2015].

[8] Barry Boehm pada artikel A Spiral Model of Software Development and Enhancement, 1988. 
Avalaiable at: 